\title{
New data on the millipede fauna of the Russian Altais, southwestern Siberia (Diplopoda)
}

\author{
Новые сведения по фауне двупарноногих многоножкек \\ российского Алтая, юг Западной Сибири (Diplopoda)
}

\author{
P.S. Nefediev ${ }^{1,2}$, J.S. Nefedieva ${ }^{3}$ \\ П.С. Нефедьев ${ }^{1,2}$, Ю.С. Нефедьева
}

\footnotetext{
${ }^{1}$ Altai State University, Lenin Avenue, 61, Barnaul 656049 Russia. E-mail: p.nefediev@mail.ru

${ }^{2}$ Tomsk State University, Lenin Avenue, 36, Tomsk 634050 Russia.

${ }^{3}$ Germes Ltd., Gogol Street, 82, Barnaul 656043 Russia. E-mail: j.nefedieva@mail.ru

${ }^{1}$ Алтайский государственный университет, проспект Ленина, 61, Барнаул 656049 Россия.

2 Томский государственный университет, проспект Ленина, 36, Томск 634050 Россия.

${ }^{3}$ ООО «Гермес», ул. Гоголя, 82, Барнаул 656043 Россия.
}

KEY WORDS: Diplopoda, Julidae, Nemasomatidae, Polydesmidae, Anthroleucosomatidae, Diplomaragnidae, Kirkayakidae, fauna, new records, Russian Altais, Siberia.

КЛЮЧЕВЫЕ СЛОВА: Diplopoda, Julidae, Nemasomatidae, Polydesmidae, Anthroleucosomatidae, Diplomaragnidae, Kirkayakidae, фауна, новые находки, Русский Алтай, Сибирь.

ABSTRACT. Based on abundant collections in the Altai region, four millipede species, Julus ghilarovi ghilarovi Gulička, 1963, Ghilarovia cylindrica (Shear, 1990), Altajosoma bakurovi bakurovi (Shear, 1990) and A. deplanatum (Stuxberg, 1876), are newly reported in the Altai Province, SW Siberia, Russia. Distribution data and remarks are provided for all species encountered.

How to cite this article: Nefediev P.S., Nefedieva J.S. 2017. New data on the millipede fauna of the Russian Altais, southwestern Siberia (Diplopoda) // Arthropoda Selecta. Vol.26. No.4. P.288-296. doi: 10.15298/arthsel.26.4.02

РЕЗЮМЕ. По обильному коллекционному материалу из Алтайского региона четыре вида двупарноногих многоножек, Julus ghilarovi ghilarovi Gulička, 1963, Ghilarovia cylindrica (Shear, 1990), Altajosoma bakurovi bakurovi (Shear, 1990) и A. deplanatum (Stuxberg, 1876), впервые отмечены на территории Алтайского края, юг Западной Сибири, Россия. Для всех видов приведены сведения по их распространению и замечания.

\section{Introduction}

According to Mikhaljova's [2017] latest review of the millipedes of the Asian part of Russia, the fauna of the Altai region within Russia, including the Altai Province and the Republic of Altai, encompasses at least 39 species or subspecies from 19 genera, nine families and three orders. One more diplomaragnid, Shearia oiskaya Mikhaljova, 2000, previously found in the Re- public of Altai [Mikhaljova et al., 2008], was omitted from the 2017 book and must be added to the list. Based on fresh faunistic material from the study area, the present paper supplements the regional list of millipedes with new records.

The material treated herein has mainly been deposited in the collection of the Altai State University, Barnaul, Russia (ASU), partly shared also with the collections of the Zoological Museum of the Lomonosov Moscow State University, Moscow, Russia (ZMUM) and the Federal Scientific Center of the East Asian Terrestrial Biodiversity, Far Eastern Branch of the Russian Academy of Sciences, Vladivostok, Russia (FSCB), as indicated in the text. Literature references to the species concern the Russian Altais only.

\section{Taxonomic part}

Class Diplopoda

Order Julida

Family JULIDAE

Julus ghilarovi ghilarovi Gulièka, 1963

Julus ghilarovi ghilarovi - Mikhaljova, Golovatch, 2001: 104; Mikhaljova, 2004: 59, 60: figs, 61: map; 2013: 8; 2016: 6; 2017: 61, figs, 63: map; Babenko et al., 2009: 183; Nefedieva, Nefediev, 2008: 123; Nefediev, Nefedieva, 2013: 87; Nefediev et al., 2014: 63; Nefedieva et al., 2014: 65; 2015: 144. 84.

non Julus ghilarovi pro parte - Mikhaljova, Nefediev, 2003:

MATERIAL EXAMINED. $4 \bigcirc^{7} \sigma^{7}, 3$ 우, 3 subadult $\sigma^{7} \sigma^{7}, 1$ subadult,+ 15 juv. (ASU), 4 우 (FSCB), Russia, southwestern Siberia, Republic of Altai, Turochak District, NW of Lake Teletskoye, $2 \mathrm{~km}$ E of Iogach, Pinus sibirica, Abies sibirica and 
Betula pendula forest with fern, $434 \mathrm{~m}$ a.s.1., 14-17.07.2004; 1 subadult $\sigma^{7}$ (ASU), same locality, $\mathrm{N}$ slope close to mountain top, 15.07.2004; 1 subadult $\sigma^{7}$ (ASU), same locality, foot of mountain, 15.07.2004; 1 ㅇ, 6 juv. (ASU), same locality, middle part of $\mathrm{N}$ slope, 17.07.2004; $8 \sigma^{7} \sigma^{7}, 11$ 우, 8 juv. (ASU), same Republic, Ulagan District, Altai State Nature Reserve, S of Lake Teletskoye, cordon Chiri, mouth of Chiri River, Betula pendula forest, 1112.08.2005; 1 o (ASU), same Republic, Turochak District, Altai State Nature Reserve, central part of Lake Teletskoye, cordon Kokshi, Betula pendula and Pinus sylvestris forest, litter, 18.08.2005; $1 \sigma^{7}, 8$ O+, 2 juv. (ASU), same Republic and District, Altai State Nature Reserve, $\mathrm{N}$ of Lake Teletskoye, Yailyu, Betula pendula and Pinus sylvestris forest, 19.08.2005, all leg. P.S. Nefediev, J.S. Nefedieva; 4 juv. (ASU), same Republic and District, Altai State Nature Reserve, NW of Lake Teletskoye, cordon Baigazan, Betula pendula, 513 m a.s.1., 3.09.2005; 1 \% , 1 क (ASU), same Republic and District, Altai State Nature Reserve, NW of Lake Teletskoye, cordon Baigazan, Padus avium, 409 m a.s.l., 3.09.2005; 2 juv. (ASU), same Republic and District, Altai State Nature Reserve, NW of Lake Teletskoye, cordon Baigazan, Populus tremula, $475 \mathrm{~m}$ a.s.1., 3.09.2005; 1 O', 2 क्ष, 1 juv. (ASU), same Republic and District, Altai State Nature Reserve, NE of Lake Teletskoye, cordon Kamga, floodplain of Malyi Meanok River, Betula pendula 6.09.2005; 2 ㅇ, 1 juv. (ASU), same Republic and District, Altai State Nature Reserve, NE of Lake Teletskoye, cordon Kamga, old fire-site, Betula pendula, 980 m a.s.1., 6.09.2005; 1 ( (ASU), same Republic and District, Altai State Nature Reserve, NW of Lake Teletskoye, cordon Baigazan, $51^{\circ} 45^{\prime} 34.9^{\prime \prime} \mathrm{N}, 87^{\circ} 25^{\prime} 55.9^{\prime \prime} \mathrm{E}$, Padu avium and Sorbus sibirica, $460 \mathrm{~m}$ a.s.1., 30.09.2013; 2 우 (ASU), same Republic and District, Altai State Nature Reserve, NW of Lake Teletskoye, cordon Baigazan, $51^{\circ} 45^{\prime} 33.7^{\prime \prime} \mathrm{N}, 87^{\circ} 25^{\prime} 58.9^{\prime \prime} \mathrm{E}$ Padus avium and Sorbus sibirica, $468 \mathrm{~m}$ a.s.1., 30.09.2013; $1 \sigma^{7}, 6$ +† (ASU), same Republic and District, Altai State Nature Reserve, NW of Lake Teletskoye, cordon Baigazan, $51^{\circ} 45^{\prime} 35.0^{\prime \prime} \mathrm{N}$, $87^{\circ} 26^{\prime} 02.3^{\prime \prime} \mathrm{E}$, Salix caprea, $482 \mathrm{~m}$ a.s.1., 30.09.2013; $2 \mathrm{O}^{\top} \sigma^{\top}, 1$ (ASU), same Republic and District, Altai State Nature Reserve, NW of Lake Teletskoye, cordon Baigazan, $51^{\circ} 45^{\prime} 34.1^{\prime \prime} \mathrm{N}$, $87^{\circ} 26^{\prime} 03.6^{\prime \prime} \mathrm{E}$, Padus avium, $490 \mathrm{~m}$ a.s.1., 1.10.2013; $1 \mathrm{\sigma}^{7}, 7$ 우 (ASU), same Republic and District, Altai State Nature Reserve, NW of Lake Teletskoye, cordon Baigazan, $51^{\circ} 45^{\prime} 32.7^{\prime \prime} \mathrm{N}$ $87^{\circ} 26^{\prime} 05.8^{\prime \prime} \mathrm{E}$, Padus avium and Betula pendula, $481 \mathrm{~m}$ a.s.1., 1.10.2013; 1 (ASU), same Republic and District, Altai State Nature Reserve, NW of Lake Teletskoye, cordon Baigazan, $51^{\circ} 45^{\prime} 34.4^{\prime \prime} \mathrm{N}, 87^{\circ} 25^{\prime} 51.3^{\prime \prime} \mathrm{E}$, Padus avium, Sorbus sibirica and Salix caprea, 465 m a.s.1., 3.10.2013; 1 juv. (ASU), same Republic and District, Altai State Nature Reserve, NW of Lake Teletskoye, cordon Baigazan, $51^{\circ} 45^{\prime} 34.4^{\prime \prime} \mathrm{N}, 87^{\circ} 25^{\prime} 45.9^{\prime \prime} \mathrm{E}$, Padus avium, 467 $\mathrm{m}$ a.s.1., 3.10.2013; $1 \mathrm{\sigma}^{7}, 1$ juv. (ASU), same Republic, Ulagan District, Altai State Nature Reserve, S of Lake Teletskoye, cordon Chiri, $51^{\circ} 21^{\prime} 40.9^{\prime \prime} \mathrm{N}, 87^{\circ} 50^{\prime} 19.7^{\prime \prime} \mathrm{E}, 444 \mathrm{~m}$ a.s.1., Betula pendula and Padus avium, 9.07.2014; $3 \sigma^{\top} \sigma^{7}, 2$ of , 1 juv. (ASU), same Republic, Turochak District, Altai State Nature Reserve, central part of Lake Teletskoye, cordon Kokshi, $51^{\circ} 34^{\prime} 35.1^{\prime \prime} \mathrm{N}$, $87^{\circ} 44^{\prime} 05.9^{\prime \prime} \mathrm{E}$, Pinus sylvestris with Spiraea, $445 \mathrm{~m}$ a.s.1., 10.06.2014; 2 juv. (ASU), same Republic and District, Altai State Nature Reserve, NE of Lake Teletskoye, cordon Kamga, $51^{\circ} 47^{\prime} 54.8^{\prime \prime} \mathrm{N}, 87^{\circ} 42^{\prime} 26.4^{\prime \prime} \mathrm{E}$, Salix and Padus avium, $438 \mathrm{~m}$ a.s.1., 10.06.2014; $4 \bigcirc^{7} \sigma^{7}, 4$ 우, 1 juv. (ASU), same Republic, Ulagan District, Altai State Nature Reserve, central part of Lake Teletskoye, cordon Chelyush, 51 $29^{\prime} 43.8^{\prime \prime} \mathrm{N}, 87^{\circ} 44^{\prime} 54.4^{\prime \prime} \mathrm{E}, 443 \mathrm{~m}$ a.s.1., Dus chekia fruticosa, 11.06.2014, all leg. M.B. Sakhnevich; $2 \sigma^{\top} \sigma^{7}, 2$ qO, 9 juv. (ASU), same Republic, Maima District, Gorno-Altaisk, floodplain of Maima River, foot of Mt Tugaya, 53⒌ $59^{\prime} 03.2^{\prime \prime N}$ $85^{\circ} 53^{\prime} 56.5^{\prime \prime E}$, Betula pendula and Acer, $276 \mathrm{~m}$ a.s.1., 9.10.2014, $15 \sigma^{7} \sigma^{7}, 25$ 우, 25 juv. (ASU), same Republic and District, GornoAltaisk, slope of Mt Tugaya, 53⒌ $59^{\prime} 01.8^{\prime \prime} \mathrm{N}, 85^{\circ} 54^{\prime} 10.8^{\prime \prime E}$, Betula pendula forest, $346 \mathrm{~m}$ a.s.1., 9.10.2014; $3 \sigma^{\top} \sigma^{\top}, 3$ 우, 1 juv., 1 fragm. (ASU), same Republic, Ongudai District, ca. 5 air-km NW of Elo, near the Lebedka Grotto, 50 $47^{\prime} 29^{\prime \prime} \mathrm{N}, 85^{\circ} 29^{\prime} 26^{\prime \prime} \mathrm{E}$, W slope with Larix sibirica, $1370 \mathrm{~m}$ a.s.1., 28.06.2016; 3 ○ $^{\top}, 18$ 우, 3 juv. (ASU), same Republic, Ulagan District, ca. 7 air-km S of Aktash, Mt Belkenek, $50^{\circ} 15^{\prime} \mathrm{N}, 87^{\circ} 37^{\prime} \mathrm{E}$, Pinus sibirica and Larix sibirica forest, $1930 \mathrm{~m}$ a.s.1., 1.07.2016; 1 ๙, 1 क (ZMUM), 1 ๙, 1 ㅇ
(FSCB), $2 \sigma^{\top} \sigma^{\top}, 10$ ㅇ, 6 subadult $\sigma^{\top} \sigma^{\top}, 9$ subadult $+\circ, 9$ juv. (ASU), same Republic and District, Altai State Nature Reserve, Stone Mushrooms (= Akkurum), 51 $06^{\prime} 40^{\prime \prime} \mathrm{N}, 87^{\circ} 58^{\prime} 33^{\prime \prime} \mathrm{E}$, Betula pendula,730 $\mathrm{m}$ a.s.1., 5.07.2016, all leg. P.S. Nefediev, J.S. Nefedieva; $7 \bigcirc^{\top}, 12$ 우, 12 juv. (ASU), Russia, southwestern Siberia, Altai Province, Zalesovo District, near Peshchiorka, $54^{\circ} 05^{\prime} 00^{\prime \prime} \mathrm{N}$, $84^{\circ} 49^{\prime} 31^{\prime \prime}$ E, Populus tremula forest with Betula pendula and Salix, $240 \mathrm{~m}$ a.s.1. 9.09.2015; $4 \sigma^{7} \sigma^{7}, 14$ 우, 2 juv. (ASU), same Province, Krasnogorskoe District, near Karaguzh, $52^{\circ} 07^{\prime} 60^{\prime \prime} \mathrm{N}$, $86^{\circ} 04^{\prime} 47^{\prime \prime} \mathrm{E}$, Alnus, Viburnum opulus and Sorbus sibirica, $260 \mathrm{~m}$ a.s.1., 15.08.2016; $1 \sigma^{\top}, 1$ (ZMUM), 1 ๙ $^{\top}, 1$ (FSCB), $4 \sigma^{\top} \sigma^{\top}, 6$ 0 , 1 juv. (ASU), same Province and District, near Karaguzh, $52^{\circ} 07^{\prime} 32^{\prime \prime} \mathrm{N}, 86^{\circ} 04^{\prime} 26^{\prime \prime} \mathrm{E}$, Betula pendula and Sorbus sibirica, 265 $\mathrm{m}$ a.s.1., 15.08.2016, all leg. P.S. Nefediev; $2 \sigma^{\top} \sigma^{\top}, 7$, 90,7 subadult $\sigma^{7} \sigma^{7}, 3$ juv. (ASU), Russia, southwestern Siberia, Kemerovo Area, Gurievsk District, along Kuzbass-Altai road, $54^{\circ} 16^{\prime} 59^{\prime \prime} \mathrm{N}$, $85^{\circ} 26^{\prime} 05^{\prime \prime} \mathrm{E}$, Betula pendula on slope, $380 \mathrm{~m}$ a.s.1., 15.07.2017, leg. P.S. Nefediev; $1 \sigma^{7}, 6$ 6 , 1 subadult $\sigma^{7}, 2$ juv. (ASU), same Area, same District, along Kuzbass-Altai road, $54^{\circ} 16^{\prime} 55^{\prime \prime} \mathrm{N}$, $85^{\circ} 26^{\prime} 00^{\prime \prime} \mathrm{E}$, Betula pendula, $370 \mathrm{~m}$ a.s.1., 11.08.2017, leg. J.S. Nefedieva, P.S. Nefediev.

DISTRIBUTION. This is the most widespread $J u$ lus species in SW Siberia, inhabiting the Kemerovo and Novosibirsk areas, the Republic of Altai, as well as the southern part of central Siberia, i.e. Republic of Khakassia and Krasnoyarsk Province; doubtful records are also from the Altai Province [Mikhaljova, 2017].

REMARKS. The previously known record of the species from the Altai Province, near Tigirek [see Mikhaljova, Nefediev, 2003], seems to be a misidentification. The above are the first valid records of the species in the Altai Province, where J. ghilarovi ghilarovi tends to dwell in the NE and SE districts at the border between the Salair Mts and the foothills of the Altais.

Leptoiulus tigirek Mikhaljova, Nefediev, Nefedieva et Dyachkov, 2015

Julus ghilarovi pro parte - Mikhaljova, Nefediev, 2003: 84. Julidae gen. sp. - Dyachkov, 2014: 41.

undescribed species of Julidae — Nefediev et al., 2014: 63

Leptoiulus tigirek Mikhaljova, Nefediev, Nefedieva, Dyachkov, 2015: 268, 269-273: figs.

Leptoiulus tigirek — Nefediev, 2016: 30; Mikhaljova, 2017: 77, 78: figs, 90: map, insets; Nefediev et al., 2017: 13.

MATERIAL EXAMINED. $1 \sigma^{\gamma}, 2$ o+ , 4 juv. (ASU), Russia, southwestern Siberia, Altai Province, Zmeinogorsk District, Tigirek State Nature Reserve, Beloretsk site, $51^{\circ} 00.277^{\prime} \mathrm{N}$, $82^{\circ} 45.830^{\prime} \mathrm{E}$, dead-surface Abies sibirica forest (chern taiga), upper part on $\mathrm{N}$ slope, $537 \mathrm{~m}$ a.s.1., pitfall traps, 28.05.-5.06.2013; 1 $\sigma^{7}$ (ASU), same Province and District, Tigirek State Nature Reserve, Beloretsk site, $51^{\circ} 00.211^{\prime} \mathrm{N}, 82^{\circ} 45.815^{\prime} \mathrm{E}$, glade in chern taiga, upper and middle parts on $\mathrm{W}$ slope, $562 \mathrm{~m}$ a.s.1., pitfall traps, 28.05.-5.06.2013; 2 + $\bigcirc$ (ASU), same Province and District, Tigirek State Nature Reserve, Beloretsk site, $51^{\circ} 00.188^{\prime} \mathrm{N}$, $82^{\circ} 45.812^{\prime} \mathrm{E}$, chern taiga, upper and middle parts on W slope, ca. $600 \mathrm{~m}$ a.s.1., pitfall traps, 28.05.-5.06.2013, all leg. T.M. Krugova; $4 \sigma^{7} \sigma^{7}$ (ASU), same Province, Krasnoshchekovo District, near Chineta, Chineta Nature Reserve, floodplain of Inya River, near bridge, $51^{\circ} 20^{\prime} 20.2^{\prime \prime} \mathrm{N}, 83^{\circ} 02^{\prime} 16.0^{\prime \prime} \mathrm{E}$, Salix with Caragana arborescens and Lonicera tatarica, on left bank, $365 \mathrm{~m}$ a.s.1., litter, 6.06.2015; $1 \sigma^{\top}, 1$, 4 juv. (ASU), same Province and District, near Chineta, Chineta Nature Reserve, $51^{\circ} 19^{\prime} \mathrm{N}, 83^{\circ} 00^{\prime} \mathrm{E}$, Betula pendula, Pinus sylvestris, Populus tremula with Caragana arborescens and Lonicera tatarica, on slope of hill, $480 \mathrm{~m}$ a.s.1., litter, 6.06.2015, all leg P.S. Nefediev, J.S. Nefedieva.

MATERIAL RE-EXAMINED (specimens published by Mikhaljova, Nefediev, 2003). 1 क, 1 subadult $\sigma^{7}, 3$ juv. (ASU), Russia, 
Altai Province, near Tigirek, lower reaches of Malyi Tigirek River, Abies and Betula forest, 17.06.2000; 2 우 (ASU), same Province, near Tigirek, upper reaches of Malyi Tigirek River, N slope of Tigirek Mt. Range, litter, under stones, 19.06.2000, all leg. A.N. Tchemeris.

DISTRIBUTION. The distribution area of the species is restricted to the Tigiretskii Mt. Range and the floodplain of the Charysh River in the SE part of the Altai Province [Mikhaljova et al., 2015; Nefediev, 2016; Mikhaljova, 2017].

REMARKS. A restudy of several specimens from the Altai Province, earlier found near Tigirek, in the lower and upper reaches of the Malyi Tigirek River, 17-19.06.2000, determined as Julus ghilarovi [see Mikhaljova, Nefediev, 2003], shows that these records actually belong to Leptoiulus tigirek.

\section{Megaphyllum sjaelandicum (Meinert, 1868)}

Julus ghilarovi pro parte - Mikhaljova, Nefediev, 2003: 84. Megaphyllum sjaelandicum - Mikhaljova et al., 2007: 62, fig; Nefediev, Nefedieva, 2007: 162; 2008b: 62; Babenko et al., 2009: 183; Mikhaljova, 2013: 9; 2016: 7; 2017: 97, 98: figs, 56: map; Nefediev et al., 2014: 63; 2017: 13.

MATERIAL EXAMINED. 2 9ᄋ (ASU), Russia, southwestern Siberia, Altai Province, Zmeinogorsk District, near Savvushka, S extremity of Lake Kolyvanskoye, Mt Bolshaya, 3.08.2007, leg. A.M. Psarev; $1 \sigma^{7}, 1$, 1 juv. (ASU), same Province, Altaiskoe District, ca. $5 \mathrm{~km} \mathrm{NW}$ of Aya, Lake Aichionok, Betula pendula stand on slope, litter, 7.07.2010, leg. P.S. Nefediev; $5 \sigma^{7} \sigma^{7}, 15 \circ 0$ 1 juv. (ASU), same Province, Krasnoshchekovo District, near Tigirek, Tigirek State Nature Reserve, Khankhara site, $51^{\circ} 11.440^{\prime} \mathrm{N}$, $82^{\circ} 58.850^{\prime} \mathrm{E}$, sparse Larix sibirica forest, 4 years old fire-site, upper part on S slope, left bank of Dragunskii Brook, pitfall traps, 23.05.-28.05.2012; $11 \sigma^{\top} \sigma^{\top}, 7$ 우, 2 juv. (ASU), same Province and District, near Tigirek, Tigirek State Nature Reserve, Khankhara site, $51^{\circ} 11.569^{\prime} \mathrm{N}, 82^{\circ} 58.740^{\prime} \mathrm{E}$, Larix sibirica forest, 4 years old fire-site, upper part on S slope, left bank of Dragunskii Brook, pitfall traps, 23.05.-1.06.2012; $2 \sigma^{\top} \sigma^{\top}, 4$ 우 (ASU), same Province, Zmeinogorsk District, Tigirek State Nature Reserve, Beloretsk site, $51^{\circ} 00.277^{\prime} \mathrm{N}, 82^{\circ} 45.830^{\prime} \mathrm{E}$, dead-surface Abies sibirica forest, upper part on $\mathrm{N}$ slope, $537 \mathrm{~m}$ a.s.1., pitfall traps, 28.05.-5.06.2013; $3 \sigma^{7} \sigma^{7}, 1$ (ASU), same Province and District, Tigirek State Nature Reserve, Beloretsk site, $51^{\circ} 00.188^{\prime} \mathrm{N}, 82^{\circ} 45.812^{\prime} \mathrm{E}$, chern taiga, upper and middle parts on $\mathrm{W}$ slope, ca. $600 \mathrm{~m}$ a.s.1., pitfall traps, 28.05.-5.06.2013, all leg. T.M. Krugova; 2 of, 34 juv. (ASU), same Province, Kranoshchekovo District, ca. $1.5 \mathrm{~km}$ NW of Tigirek, Mt Kozyr, Tigirek site, $51^{\circ} 09.219^{\prime} \mathrm{N}, 83^{\circ} 01.146^{\prime} \mathrm{E}$, sparse Larix sibirica forest, $639 \mathrm{~m}$ a.s.1., soil samples, 2.07.2013; 2 juv. (ASU), same locality, pitfall traps, 2.07.-7.07.2013; 1 +, 1 juv. (ASU) same Province and District, ca. $1.2 \mathrm{~km} \mathrm{SW}$ of Tigirek, Tigirek site, foot of Mt Chainaya, S slope, $51^{\circ} 07.765^{\prime} \mathrm{N}, 83^{\circ} 01$. $706^{\prime} \mathrm{E}$, Caragana arborescens and Lonicera tatarica thicket, 619 $\mathrm{m}$ a.s.1., pitfall traps, 2.07.-7.07.2013; 1 \%, 1 juv. (ASU), same locality, soil samples, 5.07.2013; $1 \sigma^{7}$ (ASU), same Province and District, ca. $0.75 \mathrm{~km}$ E of Tigirek, buffer zone of Tigirek State Nature Reserve, $51^{\circ} 08.613^{\prime} \mathrm{N}, 83^{\circ} 02.725^{\prime} \mathrm{E}$, Betula forest, $503 \mathrm{~m}$ a.s.1., soil samples, 4.07.2013; $1 \sigma^{7}, 16$ juv. (ASU), same Province and District, ca. $1.3 \mathrm{~km}$ SE of Tigirek, buffer zone of Tigirek State Nature Reserve, $51^{\circ} 08.247^{\prime} \mathrm{N}, 83^{\circ} 02.531^{\prime} \mathrm{E}$, stony hill, shrub thicket of Pentaphylloides fruticosa, $514 \mathrm{~m}$ a.s.1., soil samples, 10.07.2013; 2 아, 1 juv. (ASU), same Province, Charysh District, ca. $7.6 \mathrm{~km}$ SSW of Tigirek, $51^{\circ} 04.846^{\prime} \mathrm{N}, 83^{\circ} 00.309^{\prime} \mathrm{E}$, subalpine meadow in crooked Betula forest, 1268 m a.s.1., soil samples, 17.07.2013; 2 juv. (ASU), same Province, Krasnoshchekovo District, ca. $6.1 \mathrm{~km}$ SSW of Tigirek, $51^{\circ} 05.769^{\prime} \mathrm{N}, 83^{\circ} 00.733^{\prime} \mathrm{E}$, Abies sibirica forest, 1307 m a.s.1., soil samples, 18.07.2013; 1 \% (ASU), same Province and District, ca. $6.1 \mathrm{~km} \mathrm{NW}$ of Tigirek, Tigirek State Nature Reserve, Khankhara site, Betula and Salix forest, $675 \mathrm{~m}$ a.s.1., soil samples, 18.08.2014, all leg. Yu.V. Dyachkov; 5 o $\sigma^{7}, 8$ 우, 11 juv. (ASU), same Province and District, near Chineta, Chineta Nature Reserve, $51^{\circ} 19^{\prime} \mathrm{N}, 83^{\circ} 00^{\prime} \mathrm{E}$, Betula pendula, Pinus sylvestris, Populus tremula with Caragana arborescens and Lonicera tatarica, on slope of hill, $480 \mathrm{~m}$ a.s.1., litter, 6.06.2015, leg P.S. Nefediev, J.S. Nefedieva; $3 \sigma^{\top} \sigma^{\top}, 5$ 우 (ASU), same Province, Altaiskoe District, near Sarasa, broad gully Arbanak, August 2016, leg. V.N. Berdyugina.

MATERIAL RE-EXAMINED (specimen published by Mikhaljova, Nefediev, 2003). 1 フ (ASU), Russia, Altai Province, near Tigirek, lower reaches of Malyi Tigirek River, Abies and Betula forest, 17.06.2000, leg. A.N. Tchemeris.

DISTRIBUTION. The species is widespread in central and northern Europe, the European part of Russia and in southeastern Siberia (the Republic of Altai, the Novosibirsk Area and the Altai Province), also known from eastern Kazakhstan [Mikhaljova, 2017].

REMARKS. In the Altai Province, the species tends to dwell in foothill and mountainous habitats within the $\mathrm{S}$ and SE administrative districts. A restudy of the above $\sigma^{7}$ from the Altai Province, earlier found near Tigirek, lower reaches of the Malyi Tigirek River, Abies and Betula forest, 17.06.2000, identified as $J u$ lus ghilarovi by Mikhaljova, Nefediev [2003], shows that the specimen actually belongs to Megaphyllum sjaelandicum.

\section{Sibiriulus altaicus Gulička, 1963}

Cylindroiulus (Sibiriulus) altaicus Gulička, 1972: 43, 44: fig.

Cylindroiulus (Sibiriulus) altaicus - Nefediev, Nefedieva, 2008a: 117 .

Sibiriulus altaicus - Mikhaljova, 1993: 5; 2004: 75, fig, 74: map; 2016: 7; 2017: 88, 89: figs, 90: map, insets; Mikhaljova, Golovatch, 2001: 106; Mikhaljova et al., 2007: 57, 58: figs; 2014: 45, 46: figs, 51: map; Nefediev, Nefedieva, 2007: 162; 2008b: 62; 2013: 86; Nefedieva, Nefediev, 2008: 123; Nefedieva et al., 2014: 65; 2015: 146.

MATERIAL EXAMINED. $1 \sigma^{\gamma}$ (ASU), Russia, southwestern Siberia, Republic of Altai, Turochak District, Altai State Nature Reserve, NE of Lake Teletskoye, cordon Kamga, $51^{\circ} 47^{\prime} 54.8^{\prime \prime} \mathrm{N}$, 87 42'26.4"E, Salix and Padus avium, $438 \mathrm{~m}$ a.s.1., 10.06.2014, leg. M.B. Sakhnevich; $2 \sigma^{\top} \sigma^{\top}, 4$ 4 , 1 juv. (ASU), same Republic, Ulagan District, Altai State Nature Reserve, Stone Mushrooms (= Akkurum), $51^{\circ} 06^{\prime} 40^{\prime \prime} \mathrm{N}, 87^{\circ} 58^{\prime} 33^{\prime \prime} \mathrm{E}$, Betula pendula, $730 \mathrm{~m}$ a.s.1., 5.07.2016, leg. P.S. Nefediev, J.S. Nefedieva.

DISTRIBUTION. Until recently, the species has been recorded from the south of Lake Teletskoye, Republic of Altai [Mikhaljova et al., 2014]. A single male has recently been found in Gornaya Shoriya (Shorsky National Nature Park, Kemerovo Area), a territory located at the junction of the Altais, Salair Mts and Kuznetsky Alatau [Mikhaljova, 2016].

REMARKS. The above records update the distribution area of S. altaicus and are highly predictable: one of them lies between the type locality and Gornaya Shoriya, while the other one is located ca. 25 air-km south of the terra typica.

Sibiriulus latisupremus Mikhaljova, Nefediev et Nefedieva, 2014

Sibiriulus dentiger — Nefediev, 2001: 85.

Sibiriulus multinicus pro parte - Mikhaljova, Nefediev, 2003: 85, figs; Mikhaljova et al., 2007: 60, 61: figs. 
Sibiriulus latisupremus Mikhaljova, Nefediev et Nefedieva, 2014 in Mikhaljova et al., 2014: 35, 36-38: figs, 51: map. Sibiriulus latisupremus - Mikhaljova, 2017: 90, 91: figs, 92: map, insets; Nefediev et al., 2017: 13

MATERIAL EXAMINED. $5 \sigma^{\top} \sigma^{7}, 3$ o, , 6 juv. (ASU), Russia, southwestern Siberia, Republic of Altai, Ongudai District, Seminskii Pass, Pinus sibirica and Betula forest, 2.07.2014; $1 \sigma^{7}, 1+$ (ZMUM), 1 ๙ , 2 + + , 6 juv. (FSCB), same Republic and District, Seminskii Pass, alpine meadow, 2.07.2014, all leg. Yu.V. Dyachkov; $1 \sigma^{7}, 1$ ㅇ (ASU), Russia, southwestern Siberia, Altai Province, Altaiskoe District, near Altaiskoe, foot of Mt Prokhodnaya, Betula stand, pitfall traps, 9.09.2016, leg. I.N. Kudinova.

DISTRIBUTION. Being an Altai endemic, the species has been reported in the $\mathrm{E}$ and SE parts of the Altai Province, as well as from the SW part of the Republic of Altai [Mikhaljova et al., 2014; Nefediev et al., 2017].

REMARKS. The new samples of S. latisupremus from the environs of the Seminskii Pass at about 1700 $\mathrm{m}$ a.s.l. seem to be the highest altitude records of the species.

\section{Sibiriulus profugus (Stuxberg, 1876)}

non Sibiriulus dentiger — Nefediev, 2001: 85.

Sibiriulus profugus — Mikhaljova et al., 2014: 33, 34: figs, 51: map; Mikhaljova, 2017: 85, 86: figs, 85: map, insets.

MATERIAL EXAMINED. $22 \sigma^{7} \sigma^{7}, 11$ 우 (ASU), Russia southwestern Siberia, Altai Province, Kosikha District, near Ozero-Krasilovo, Altai State University Students' Field Station, 53 $11^{\prime} 23.6^{\prime \prime} \mathrm{N}, 84^{\circ} 21^{\prime} 23.8^{\prime \prime} \mathrm{E}$, Pinus sylvestris, Betula pendula and Populus tremula forest with fern, $256 \mathrm{~m}$ a.s.l., pitfall traps, 30.06.5.07.2014; $9 \sigma^{7} \sigma^{7}, 8$ 우, 1 juv. (ASU), same locality, pitfall traps, 5.07.-10.07.2014; $9 \sigma^{\top} \sigma^{7}, 26$ 우, 11 juv. (ASU), same Province,

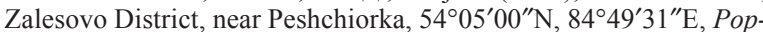
ulus tremula forest with Betula pendula and Salix, $240 \mathrm{~m}$ a.s.1. 9.09.2015, all leg. P.S. Nefediev; 1 ○ (ASU), same Province, Troitskoe District, near Chervyanka, Betula forest, 23.06.-3.07. 2016, leg. N.M. Vyatkina.

DISTRIBUTION. This species is the most widespread Sibiriulus, dwelling in southwestern (the Tomsk, Novosibirsk and Kemerovo areas, the Altai Province and the Republic of Altai) and central Siberia (the southern part of the Krasnoyarsk Province and the Republic of Khakassia) [Mikhaljova et al., 2014; Mikhaljova, 2017].

REMARKS. In the Altai Province, the species appears to occur in a riparian forest massif near the $\mathrm{Ob}$ River between the cities of Biysk and Barnaul, as well as in the NE part of the Province in the Salair Mts.

\section{Sibiriulus rectangulus Mikhaljova, 2009}

Sibiriulus rectangulus Mikhaljova, 2009: 67, 65: figs. Sibiriulus rectangulus — Mikhaljova et al., 2014: 37, 49: figs, 51: map; Mikhaljova, 2017: 83, 84: figs, 85: map, insets.

MATERIAL EXAMINED. 1 \%, 1 ( 9 (ZMUM), 1 ๆ, 8 우, 2 juv. (ASU), Russia, southwestern Siberia, Republic of Altai, Maima District, Gorno-Altaisk, floodplain of Maima River, foot of Mt Tugaya, $53^{\circ} 59^{\prime} 03.2^{\prime \prime} \mathrm{N}, 85^{\circ} 53^{\prime} 56.5^{\prime \prime} \mathrm{E}$, Betula pendula and Acer, 276 m a.s.1., 9.10.2014; $2 \sigma^{\top} \sigma^{7}, 1$ subadult $\sigma^{7}, 1$ juv. (ASU), same Republic and District, Gorno-Altaisk, slope of Mt Tugaya, $53^{\circ} 59^{\prime} 01.8^{\prime \prime} \mathrm{N}, 85^{\circ} 54^{\prime} 10.8^{\prime \prime} \mathrm{E}$, Betula pendula forest, $346 \mathrm{~m}$ a.s.1., 9.10.2014, all leg. P.S. Nefediev, J.S. Nefedieva.

DISTRIBUTION. The species is only known from the environs of Gorno-Altaisk, the capital city of the Republic of Altai [Mikhaljova, 2009, 2017; Mikhaljova et al., 2014].
REMARKS. Being a second formal record of $S$. rectangulus from near its terra typica, the above samples may be referred to as topotypes.

\section{Family NEMASOMATIDAE}

\section{Orinisobates sibiricus (Gulička, 1963)}

Orinisobates sibiricus — Enghoff, 1985: 53, 54: figs, 50: map; Mikhaljova, 1993: 5; 2004: 96, figs, 94: map; 2016: 9; 2017: 120, 121: figs, 122: map; Mikhaljova, Golovatch, 2001: 107; Mikhaljova, Nefediev, 2003: 83; Nefedieva, Nefediev 2008: 123; Nefediev, Nefedieva, 2013: 87; Nefediev et al., 2014: 63; 2017: 13; Nefedieva et al., 2014: 65; 2015: 147

MATERIAL EXAMINED. $5 \sigma^{7} \sigma^{7}, 14$ 우, 1 juv. (ASU), Russia, southwestern Siberia, Republic of Altai, Turochak District, NW of Lake Teletskoye, $2 \mathrm{~km}$ E of Iogach, Pinus sibirica, Abies sibirica and Betula pendula forest with fern, $434 \mathrm{~m}$ a.s.1., 14 17.07.2004; $63 \bigcirc^{7} \bigcirc^{7}, 59$ 우, 22 juv. (ASU), same Republic, Ulagan District, Kalbakaya River, Betula rotundifolia, in moss, 25.07.2006; 1 ऽ , 4 ㅇ, 1 juv. (ASU), same Republic and District, Altai State Nature Reserve, $9 \mathrm{~km} \mathrm{~S}$ of Lake Dzhulukul, near PakYyash Lakes, Betula rotundifolia, $2200 \mathrm{~m}$ a.s.1., 27.07.2006; 20 $\sigma^{7} \sigma^{7}, 21$ 오, 4 juv. (ASU), same Republic and District, Altai State Nature Reserve, Lake Dzhulukul, Betula rotundifolia, in moss, 28.07.2006; $10 \sigma^{\top} \sigma^{\top}, 25$ ㅇ, 2 juv. (ASU), same Republic, KoshAgach District, ca. 14 air-km NW of Chagan-Uzun, floodplain of Chuya River, on right bank, stony steppe, under stones in grassy glades, 11.08.2006; 1 ㅇ (ASU), same Republic, Ongudai District, old road of Chike-Taman Pass, Caragana arborescens, 5.08.2007; $8 \sigma^{\top} \sigma^{7}, 6$ 우 (ASU), same Republic and District, ca. 3 air-km SW of Chyi-Oozy, confluence of Chuya River with Katun River, Caragana arborescens and Pentaphylloides fruticosa, 5.08.2007; 2 OO (ASU), same Republic, Ulagan District, ca. 18 air-km NNW of Aktash, NW part of Lake Sorulukel, foot of N slope of Aigulakskii Mt. Range, Pinus sibirica and Larix sibirica forest with Betula rotundifolia, Vaccinium vitis-idaea, Equisetum, Sphagnum, 11.08.2007; 1 (ASU), same Republic and District, ca. 18 air-km NNW of Aktash, Lake Sorulukel, Betula rotundifolia, 13.08.2007, all leg. P.S. Nefediev, J.S. Nefedieva; 1 or, 3 ㅇ (ASU), same Republic, Turochak District, Altai State Nature Reserve, NW of Lake Teletskoye, cordon Baigazan, $51^{\circ} 45^{\prime} 34.9^{\prime \prime} \mathrm{N}, 87^{\circ} 25^{\prime} 55.9^{\prime \prime} \mathrm{E}$, Padus avium and Sorbus sibirica, $460 \mathrm{~m}$ a.s.1., 30.09.2013; 3 우 (ASU), same Republic and District, Altai State Nature Reserve, NW of Lake Teletskoye, cordon Baigazan, $51^{\circ} 45^{\prime} 33.7^{\prime \prime} \mathrm{N}, 87^{\circ} 25^{\prime}$ 58.9"E, Padus avium and Sorbus sibirica, $468 \mathrm{~m}$ a.s.1., 30.09.2013; $1 \sigma^{\top}$ (ASU), same Republic and District, Altai State Nature Reserve, NW of Lake Teletskoye, cordon Baigazan, $51^{\circ} 45^{\prime} 35.0^{\prime \prime} \mathrm{N}$, $87^{\circ} 26^{\prime} 02.3^{\prime \prime}$ E, Salix caprea, $482 \mathrm{~m}$ a.s.1., 30.09.2013; 1 ㅇ (ASU), same Republic and District, Altai State Nature Reserve, NW of Lake Teletskoye, cordon Baigazan, $51^{\circ} 45^{\prime} 32.1^{\prime \prime} \mathrm{N}, 87^{\circ} 25^{\prime} 54.8^{\prime \prime} \mathrm{E}$, Padus avium, $454 \mathrm{~m}$ a.s.1., 1.10.2013; 1 \% (ASU), same Republic and District, Altai State Nature Reserve, NW of Lake Teletskoye, cordon Baigazan, $51^{\circ} 45^{\prime} 32.7^{\prime \prime} \mathrm{N}, 87^{\circ} 26^{\prime} 05.8^{\prime \prime} \mathrm{E}$, Padus avium and Betula pendula, $481 \mathrm{~m}$ a.s.1., 1.10.2013; $1 \sigma^{7}, 6$ 우, 1 juv. (ASU), same Republic and District, Altai State Nature Reserve, NW of Lake Teletskoye, cordon Baigazan, $51^{\circ} 45^{\prime} 34.4^{\prime \prime} \mathrm{N}, 87^{\circ} 25^{\prime} 51.3^{\prime \prime} \mathrm{E}$, Padus avium, Sorbus sibirica and Salix caprea, $465 \mathrm{~m}$ a.s.1., 3.10.2013; 3 우 (ASU), same Republic and District, Altai State Nature Reserve, NW of Lake Teletskoye, cordon Baigazan, $51^{\circ} 45^{\prime} 34.4^{\prime \prime} \mathrm{N}, 87^{\circ} 25^{\prime} 45.9^{\prime \prime} \mathrm{E}$, Padus avium, $467 \mathrm{~m}$ a.s.1., 3.10.2013; $1 \sigma^{7}, 3$ OO (ASU), same Republic and District, Altai State Nature Reserve, NW of Lake Teletskoye, cordon Baigazan, $51^{\circ} 45^{\prime} 35.0^{\prime \prime} \mathrm{N}$, $87^{\circ} 25^{\prime} 42.2^{\prime \prime} \mathrm{E}$, Padus avium, $470 \mathrm{~m}$ a.s.1., 3.10.2013; 1 9 (ASU), same Republic and District, Altai State Nature Reserve, NW of Lake Teletskoye, cordon Baigazan, $51^{\circ} 45^{\prime} 31.6^{\prime \prime} \mathrm{N}, 87^{\circ} 25^{\prime} 39.1^{\prime \prime} \mathrm{E}$, Padus avium, Salix caprea and Betula pendula, $448 \mathrm{~m}$ a.s.1., 3.10.2013, all leg M.B. Sakhnevich; $1 \sigma^{7}, 1$ q (ZMUM), $1 \sigma^{\gamma}, 1$ 우 (FSCB), $4 \bigcirc^{\top} \sigma^{7}, 11$ 우 (ASU), same Republic, Kosh-Agach District, mouth of Karagem River, Larix sibirica and Pinus sibirica forest, along brook, under stones, 28.06.2014, leg. Yu.V. Dyachk- 
ov; $3 \sigma^{7} \sigma^{7}, 1$ juv. (ASU), same Republic, Maima District, GornoAltaisk, slope of Mt Tugaya, 53⒌ $01.8^{\prime \prime} \mathrm{N}, 85^{\circ} 54^{\prime} 10.8^{\prime \prime} \mathrm{E}$, Betula pendula forest, $346 \mathrm{~m}$ a.s.1., 9.10.2014, leg. P.S. Nefediev, J.S. Nefedieva; $1 \sigma^{\gamma}, 2$ 우 (ASU), same Republic, Ulagan District, ca. 1 $\mathrm{km} \mathrm{S}$ of Balykcha, floodplain of Chulyshman River, $51^{\circ} 16^{\prime} 19.6^{\prime \prime} \mathrm{N}$ $87^{\circ} 43^{\prime} 22.2^{\prime \prime} \mathrm{E}$, meadow, $500 \mathrm{~m}$ a.s.1., 4.06.2016; 1 \% (ASU), same Republic and District, Altai State Nature Reserve, mouth of Karasu River near Stone Mushrooms (= Akkurum), $51^{\circ} 06^{\prime} 25.5^{\prime \prime} \mathrm{N}$ 87 58'44.1"E, Populus, 560 m a.s.1., 5.06.2016, all leg. P.S. Nefediev; $1 \sigma^{7}$ (ASU), Russia, southwestern Siberia, Altai Province, Krasnoshchekovo District, ca. $1 \mathrm{~km} \mathrm{SW}$ of Tigirek, Tigirek site, S slope of Mt Chainaya, $51^{\circ} 07.797^{\prime} \mathrm{N}, 83^{\circ} 01.658^{\prime} \mathrm{E}$, meadow steppe, $644 \mathrm{~m}$ a.s.1., pitfall traps, 30.06.-5.07.2013; 2 우 (ASU), same Province, Zmeinogorsk District, ca. $12 \mathrm{~km}$ SSW of Tigirek, Tigirek State Nature Reserve, Beloretsk site, $51^{\circ} 02.444^{\prime} \mathrm{N}, 82^{\circ} 57.658^{\prime} \mathrm{E}$, subalpine meadow, $1346 \mathrm{~m}$ a.s.1., pitfall traps, 22-26.08.2014, all leg. Yu.V. Dyachkov; $2 \sigma^{7} \sigma^{7}$ (ASU), same Province and District, near Chineta, Chineta Nature Reserve, $51^{\circ} 19^{\prime} \mathrm{N}, 83^{\circ} 00^{\prime} \mathrm{E}$, Betula pendula, Pinus sylvestris, Populus tremula with Caragana arborescens and Lonicera tatarica, on slope of hill, $480 \mathrm{~m}$ a.s.1., litter, 6.06.2015, leg. P.S. Nefediev, J.S. Nefedieva; $4 \sigma^{\top} \sigma^{\top}, 11$ t 1 fragm. (ASU), Russia, south of central Siberia, Republic of Khakassia, Shira District, near Kommunar, bald Mt (= golets) Podoblachnyi, August 2004, leg. E.V. Miroshnichenko; 1 (ASU), Russia, southwestern Siberia, Kemerovo Area, Gurievsk District, along Kuzbass-Altai road, $54^{\circ} 16^{\prime} 55^{\prime \prime} \mathrm{N}, 85^{\circ} 26^{\prime} 00^{\prime \prime} \mathrm{E}$, Betula pendula, $370 \mathrm{~m}$ a.s.1., 11.08.2017, leg. J.S. Nefedieva, P.S. Nefediev.

DISTRIBUTION. The species is highly widespread in Central Asia: being originally described from the Kemerovo Area, O. sibiricus has since been recorded from adjacent Russian administrative units in SW Siberia, i.e. the Republic of Altai and the Altai Province, likewise from central and eastern Siberia (the southern part of the Krasnoyarsk Province, the Khakassian and Tyva republics, and the Zabaikalskii Province); also known from eastern Kazakhstan and Kyrgyzstan [Mikhaljova, Nefediev, 2003; Mikhaljova, 2017].

REMARKS. Based on the material studied, the number of setae on each lamella lingualis of the gnathochilarium is variable $(4+4,5+3$ vs $3+3$ in the redescription [see Enghoff, 1985]).

\section{Order Polydesmida \\ Family POLYDESMIDAE}

\section{Schizoturanius clavatipes (Stuxberg, 1876)}

Schizoturanius clavatipes — Nefediev, 2001: 85; Mikhaljova, Golovatch, 2001: 116; Mikhaljova, Nefediev, 2003: 81; Mikhaljova, 2004: 238, 239: figs, 228: map; 2013: 9; 2016: 24; 2017: 288, 289: figs, 290: map; Nefedieva, Nefediev, 2008: 123; Nefediev, Nefedieva, 2013: 87; Nefediev et al., 2014: 63; 2017: 13; Nefedieva et al., 2014: 65; 2015: 152.

MATERIAL EXAMINED. 11 juv. (ASU), Russia, southwestern Siberia, Republic of Altai, Turochak District, NW of Lake Teletskoye, $2 \mathrm{~km}$ E of Iogach, Pinus sibirica, Abies sibirica and Betula pendula forest with fern, $434 \mathrm{~m}$ a.s.1., 14-17.07.2004; 1 juv. (ASU), same locality, on $\mathrm{N}$ slope close to mountain top, 15.07.2004; $2 \sigma^{7} \sigma^{7}, 1$ juv. (ASU), same Republic, Ulagan District, Altai State Nature Reserve, S of Lake Teletskoye, cordon Chiri, mouth of Chiri River, Betula pendula forest, 11-12.08.2005; 3 juv. (ASU), same Republic and District, Altai State Nature Reserve, S of Lake Teletskoye, near cordon Chiri, hut in upper reaches of Bayas River, sparse Pinus sibirica stand, $1600 \mathrm{~m}$ a.s.1., 14.08.2005; 1 ○', 2 우, 1 juv. (ASU), same Republic, Turochak District, Altai State Nature Reserve, N of Lake Teletskoye, Yailyu, Betula pendula and Pinus sylvestris forest, 19.08.2005, all leg. P.S. Nefediev, J.S. Nefedieva; $1+$ (ASU), same Republic and District, Altai State Nature Reserve, NW of Lake Teletskoye, cor- don Baigazan, Sorbus sibirica and Salix, $447 \mathrm{~m}$ a.s.1., 3.09.2005; 2 $\sigma^{7} \sigma^{7}$ (ASU), same Republic and District, Altai State Nature Reserve, NW of Lake Teletskoye, cordon Baigazan, $51^{\circ} 45^{\prime} 33.7^{\prime \prime} \mathrm{N}$, $87^{\circ} 25^{\prime} 58.9^{\prime \prime} \mathrm{E}$, Padus avium and Sorbus sibirica, $468 \mathrm{~m}$ a.s.1., 30.09.2013; $1 \sigma^{7}$ (ASU), same Republic and District, Altai State Nature Reserve, NW of Lake Teletskoye, cordon Baigazan, $51^{\circ} 45^{\prime} 32.7^{\prime \prime} \mathrm{N}, 87^{\circ} 26^{\prime} 05.8^{\prime \prime} \mathrm{E}$, Padus avium and Betula pendula, $481 \mathrm{~m}$ a.s.1., 1.10.2013; $2 \mathrm{\sigma}^{\top} \sigma^{\top}, 2$ + 20 (ASU), same Republic and District, Altai State Nature Reserve, NW of Lake Teletskoye, cordon Baigazan, $51^{\circ} 45^{\prime} 34.4^{\prime \prime} \mathrm{N}, 87^{\circ} 25^{\prime} 45.9^{\prime \prime} \mathrm{E}$, Padus avium, $467 \mathrm{~m}$ a.s.1., 3.10.2013; $5 \sigma^{\top} \sigma^{\top}, 1$ (ASU), same Republic and District, Altai State Nature Reserve, NW of Lake Teletskoye, cordon Baigazan, $51^{\circ} 45^{\prime} 35.0^{\prime \prime} \mathrm{N}, 87^{\circ} 25^{\prime} 42.2^{\prime \prime} \mathrm{E}$, Padus avium, $470 \mathrm{~m}$ a.s.1., 3.10.2013; 1 \% , 3 우 (ASU), same Republic and District, Altai State Nature Reserve, NW of Lake Teletskoye, cordon Baigazan, $51^{\circ} 45^{\prime} 31.6^{\prime \prime} \mathrm{N}, 87^{\circ} 25^{\prime} 39.1^{\prime \prime} \mathrm{E}$, Padus avium, Salix caprea and Betula pendula, $448 \mathrm{~m}$ a.s.1., 3.10.2013, all leg. M.B. Sakhnevich; 4 juv. (ASU), same Republic, Ongudai District, Seminskii Pass, alpine meadow, 2.07.2014, leg. Yu.V. Dyachkov; $1 \sigma^{\top}, 2$ 우 (ASU), same Republic, Maima District, Gorno-Altaisk, slope of Mt Tugaya, $53^{\circ} 59^{\prime} 01.8^{\prime \prime} \mathrm{N}, 8^{\circ} 54^{\prime} 10.8^{\prime \prime} \mathrm{E}$, Betula pendula forest, $346 \mathrm{~m}$ a.s.1., 9.10.2014, leg. P.S. Nefediev, J.S. Nefedieva; $1 \sigma^{\top}$ (ASU), Russia, southwestern Siberia, Altai Province, Biysk, Sorokino, Pinus sylvestris, Populus tremula and Betula pendula forest with Padus avium, on Armillaria, 13.09.2008, leg. P.S. Nefediev, J.S. Nefedieva; 1 $\mathrm{O}^{7}, 3$ juv. (ASU), same Province, Biysk, Odintsovka, Salix along brook, 19.06.2009; $5 \sigma^{\top} \sigma^{\top}, 2$ 우 (ASU), same Province, Biysk, Molodezhnyi, right bank of Biya River, Betula pendula and Salix, litter, 13.10.2009; 1 \%, 3 juv. (ASU), same Province, Altaiskoe District, ca. $5 \mathrm{~km} \mathrm{NW}$ of Aya, Lake Aichionok, Betula pendula stand on slope, litter, 7.07.2010, all leg. P.S. Nefediev; $1 \sigma^{7}, 2$, 1 fragm. (ASU), same Province, Krasnoshchekovo District, near Tigirek, Tigirek State Nature Reserve, Khankhara site, $51^{\circ} 11.569^{\prime} \mathrm{N}$, $82^{\circ} 58.740^{\prime} \mathrm{E}$, Larix sibirica forest, 4-year old fire-site, upper part on S slope, left bank of Dragunskii Brook, pitfall traps, 23.05.1.06.2012; $2 \sigma^{7} \sigma^{7}$ (ASU), same Province, Zmeinogorsk District, Tigirek State Nature Reserve, Beloretsk site, $51^{\circ} 00.277^{\prime} \mathrm{N}$, $82^{\circ} 45.830^{\prime} \mathrm{E}$, dead-surface Abies sibirica forest (chern taiga), upper part on $\mathrm{N}$ slope, $537 \mathrm{~m}$ a.s.1., pitfall traps, 28.05.-5.06.2013, all leg. T.M. Krugova; $5 \sigma^{\top} \sigma^{\top}, 2$ 우 (ASU), same Province, Smolenskoe District, Smolenskoe, floodplain of Poperechka River, Populus, 21.04.2013, leg. P.S. Nefedieva, J.S. Nefedieva; 10 juv. (ASU), same Province, Krasnoshchekovo District, ca. $0.75 \mathrm{~km} \mathrm{E}$ of Tigirek, buffer zone of Tigirek State Nature Reserve, $51^{\circ} 08.613^{\prime} \mathrm{N}$, $83^{\circ} 02.725^{\prime} \mathrm{E}$, Betula forest, $503 \mathrm{~m}$ a.s.1., pitfall traps, 1.07.6.07.2013; $2 \sigma^{\top} \sigma^{\top}, 3$ 우, 33 juv., 2 fragm. (ASU), same locality, soil samples, 4.07.2013, all leg. Yu.V. Dyachkov; 1 q (ASU), same Province, Barnaul, "Lesnaya Skazka" Park, Acer and Betula, under

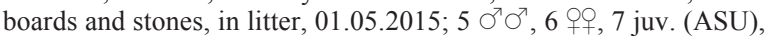
same Province, Zalesovo District, near Peshchiorka, 54 $05^{\prime} 00^{\prime \prime} \mathrm{N}$, $84^{\circ} 49^{\prime} 31^{\prime \prime}$ E, Populus tremula forest with Betula pendula and Salix, 240 m a.s.1. 9.09.2015; $3 \bigcirc^{\top} \sigma^{\top}, 2$ 우 (ASU), same Province, Krasnogorskoe District, near Karaguzh, $52^{\circ} 07^{\prime} 60^{\prime \prime} \mathrm{N}, 86^{\circ} 04^{\prime} 47^{\prime \prime} \mathrm{E}, \mathrm{Al}$ nus, Viburnum opulus and Sorbus sibirica, $260 \mathrm{~m}$ a.s.1., 15.08.2016; 1 (ASU), same Province and District, near Karaguzh, $52^{\circ} 07^{\prime} 32^{\prime \prime} \mathrm{N}$, $86^{\circ} 04^{\prime} 26^{\prime \prime} \mathrm{E}$, Betula pendula and Sorbus sibirica, $265 \mathrm{~m}$ a.s.1., 15.08.2016, all leg. P.S. Nefediev; $1 \sigma^{7}, 1$ juv. (ASU), same Province, Krasnogorskoe District, $3 \mathrm{~km} \mathrm{~N}$ of Bystryanka, Acer and Alnus stands along Chuya Tract, 52 $19^{\prime} 39^{\prime \prime} \mathrm{N}, 85^{\circ} 49^{\prime} 38^{\prime \prime} \mathrm{E}, 215 \mathrm{~m}$ a.s.1., 15.08.2016, leg. P.S. Nefediev, J.S. Nefedieva.

DISTRIBUTION AND REMARKS. This species is very widespread throughout southwestern and central Siberia: the Kemerovo, Novosibirsk and Tomsk areas, the Altai and Krasnoyarsk provinces, the Altai and Khakassian republics [Mikhaljova, 2017]. Thus, the species is obviously high in ecological valence.

\section{Schizoturanius tabescens (Stuxberg, 1876)}

Schizoturanius salairicus - Nefediev, 2001: 85; Mikhaljova, Nefediev, 2003: 83 
Schizoturanius tabescens - Mikhaljova, 2004: 240, 241: figs, 242: map; 2017: 291, figs, 292: map; Mikhaljova, Marusik, 2004: 8, 7: figs; Nefedieva, Nefediev, 2008: 123; Babenko et al., 2009: 183; Nefediev, Nefedieva, 2013: 87; Nefedieva et al., 2014: 65; 2015: 153

MATERIAL EXAMINED. 18 O, 15 juv. (ASU), Russia, southwestern Siberia, Republic of Altai, Turochak District, NW of Lake Teletskoye, $2 \mathrm{~km}$ E of Iogach, Pinus sibirica, Abies sibirica and Betula pendula forest with fern, $434 \mathrm{~m}$ a.s.1., 14-17.07.2004; 2 क् (ASU), same locality, middle part of N slope, 17.07.2004; 1 (ASU), same Republic, Maima District, Gorno-Altaisk, slope of Mt Tugaya, 53⒌'01.8"N, 8554'10.8"E, Betula pendula forest, $346 \mathrm{~m}$ a.s.1., 9.10.2014; 3 OO (ASU), same Republic, Ongudai District, near Belyi Bom, right bank of Chuya River, along road to Shavla Nature Reserve, Ribes nigrum thicket, 21.07.2006; 1 \% (ASU), same Republic and District, Tutugoi River, Betula pendula, 9.08.2006, all leg. P.S. Nefediev, J.S. Nefedieva; 27 juv. (ASU), Russia, southwestern Siberia, Altai Province, Pervomaiskii District, near Kostyaki, Betula pendula and Pinus sylvestris forest, 19.08.2007; 1 juv. (ASU), same Province and District, near Sibirskii, Betula pendula and Pinus sylvestris forest, 24.08.2007, all leg. P.S. Nefediev, J.S. Nefedieva; 1 \& (ASU), same Province, Kosikha District, ca. $5 \mathrm{~km} \mathrm{NW}$ of Polkovnikovo, Betula pendula, litter, 4.05.2009; 4 우, 8 juv. (ASU), same Province, Pervomaiskii District, Beriozki Railway Station, "Motorostroitel" Gardening Partnership, $53^{\circ} 33^{\prime} 35.8^{\prime \prime} \mathrm{N}, 83^{\circ} 44^{\prime} 48.7^{\prime \prime} \mathrm{E}$, open hand-made ground, $225 \mathrm{~m}$ a.s.1., 12.06.2010; 2 우 (ASU), same locality, onion bed, 30.06.2013; 9 우, 1 juv. (ASU), same locality, 7.06.2014; 4 ऽ $\sigma^{\top}$, 19 ㅇ, 1 juv. (ASU), same locality, 6-20.09.2014, all leg. P.S. Nefediev; 14 ㅇ, 27 juv. (ASU), same Province, Barnaul, Yuzhnyi, South Siberian Botanical Garden, open hand-made ground with flowers and fruit trees, under boards and paving tiles of footpaths between beds, 19.06.2013, leg. P.S. Nefediev, Yu.V. Dyachkov; 1 q (ASU), same Province, Krasnoshchekovo District, ca. 0.75 km E of Tigirek, buffer zone of Tigirek State Nature Reserve, $51^{\circ} 08.613^{\prime} \mathrm{N}, 83^{\circ} 02.725^{\prime} \mathrm{E}$, Betula forest, $503 \mathrm{~m}$ a.s.1., pitfall traps, 1.07.-6.07.2013, leg. Yu.V. Dyachkov; 2 ๆ0, 1 juv. (ASU), same Province, Kosikha District, near Ozero-Krasilovo, Altai State Uni-

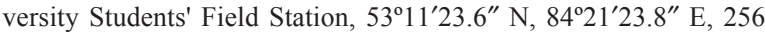
$\mathrm{m}$ a.s.1., Populus tremula forest with Pinus sylvestris, Betula pendula and ferns, tall grass vegetation, pitfall traps, 30.06.-10.07.2014; $1 \sigma^{7}, 19$ 우, 3 juv. (ASU), same Province, Zalesovo District, near Peshchiorka, $54^{\circ} 05^{\prime} 00^{\prime \prime} \mathrm{N}, 84^{\circ} 49^{\prime} 31^{\prime \prime} \mathrm{E}$, Populus tremula forest with Betula pendula and Salix, $240 \mathrm{~m}$ a.s.1. 9.09.2015, all leg. P.S Nefediev; 1 juv. (ASU), same Province, Solton District, near Akatievo, Populus, 22.06.2016, leg. J.S. Nefedieva; 1 (ASU), same Province, Krasnogorskoe District, near Karaguzh, $52^{\circ} 07^{\prime} 60^{\prime \prime} \mathrm{N}$, $86^{\circ} 04^{\prime} 47^{\prime \prime} \mathrm{E}$, Alnus, Viburnum opulus and Sorbus sibirica, $260 \mathrm{~m}$ a.s.1., 15.08.2016, leg. P.S. Nefediev.

DISTRIBUTION AND REMARKS. The species seems to be rather widespread in southwestern and central Siberia, i.e. the Kemerovo, Tomsk and Novosibirsk areas, the Krasnoyarsk and Altai provinces, the Khakassian and Altai republics [Mikhaljova, 2017]. Hence, S. tabescens is characterized by high ecological plasticity.

\section{Order Chordeumatida \\ Family ANTHROLEUCOSOMATIDAE}

Ghilarovia cylindrica (Shear, 1990)

MATERIAL EXAMINED. $5 \sigma^{\top} \sigma^{\top}, 6$ ㅇ (ASU), Russia, southwestern Siberia, Altai Province, Zalesovo District, near Peshchiorka, $54^{\circ} 05^{\prime} 00^{\prime \prime} \mathrm{N}, 84^{\circ} 49^{\prime} 31^{\prime \prime} \mathrm{E}$, Populus tremula forest with Betula pendula and Salix, $240 \mathrm{~m}$ a.s.1. 9.09.2015, leg. P.S. Nefediev.

DISTRIBUTION. Up to now, this species has only been known from the Tomsk, Kemerovo and Novosi- birsk areas, the southern part of the Krasnoyarsk Province, and the Republic of Khakassia [Mikhaljova, 2017].

REMARKS. Being widespread in the southern taiga of SW Siberia, G. cylindrica seems to have penetrated the NE part of the Altai Province from the Salair Mts in the Kemerovo Area, from where it is freshly reported.

\section{Ghilarovia kygae Gulička, 1972}

Ghilarovia kygae Gulička, 1972: 39, 40: figs.

Ghilarovia kygae - Shear, 1988: 54, 55: figs; Mikhaljova, 1993: 6; 2002: 203; 2017: 231, figs, 191: map; Shelley et al., 2000: 68; Mikhaljova, Golovatch, 2001: 107; Nefediev, Nefedieva, 2007: 162; 2008a: 117; 2008b: 62; 2013: 87; Nefedieva, Nefediev, 2008: 123; Nefedieva et al., 2014: 65; 2015: 150.

non Ghilarovia kygae pro parte - Mikhaljova, Golovatch, 2001: 107.

MATERIAL EXAMINED. 34 subadult $\sigma^{\top} \sigma^{\top}, 40$ subadult $\circ \circ$, 1 juv. (ASU), Russia, southwestern Siberia, Republic of Altai, Turochak District, NW of Lake Teletskoye, $2 \mathrm{~km} \mathrm{E}$ of Iogach, Pinus sibirica, Abies sibirica and Betula pendula forest with fern, $434 \mathrm{~m}$ a.s.1., 14-17.07.2004; 7 subadult $\sigma^{7} \sigma^{7}, 4$ subadult same locality, on $\mathrm{N}$ slope close to mountain top, 15.07.2004; 1 subadult $\sigma^{\gamma}, 5$ juv. (ASU), same locality, foot of mountain, 15.07.2004; 3 subadult $\sigma^{\top} \sigma^{\top}, 4$ subadult +,+ 1 juv. (ASU), same locality, middle part of N slope, 17.07.2004; $16 \sigma^{7} \sigma^{7}, 29$ O0, 6 juv. (ASU), same Republic, Ulagan District, Altai State Nature Reserve, S of Lake Teletskoye, cordon Chiri, mouth of Chiri River, Betula pendula forest, 11-12.08.2005; $2 \sigma^{\top} \sigma^{7}, 8$ 오, 1 fragm. (ASU), same Republic and District, Altai State Nature Reserve, S of Lake Teletskoye, near cordon Chiri, hut in upper reaches of Bayas River, sparse Pinus sibirica stand, 1600 m a.s.1., 14.08.2005; 1 (ASU), same Republic, Turochak District, Altai State Nature Reserve, central part of Lake Teletskoye, cordon Kokshi, Betula pendula and Pinus sylvestris forest, litter, 18.08.2005; 2 우 (ASU), same Republic and District, Altai State Nature Reserve, N of Lake Teletskoye, Yailyu, Betula pendula and Pinus sylvestris forest, 19.08.2005, all leg. P.S. Nefediev, J.S. Nefedieva; 1 juv. (ASU), same Republic and District, Altai State Nature Reserve, NW of Lake Teletskoye, cordon Baigazan, Padus avium, $409 \mathrm{~m}$ a.s.1., 3.09.2005; $2 \sigma^{\top} \sigma^{7}, 2$ 우, 1 juv. (ASU), same Republic and District, Altai State Nature Reserve, NW of Lake Teletskoye, cordon Baigazan, Populus tremula, $475 \mathrm{~m}$ a.s.1., 3.09.2005; $4 \sigma^{\top} \sigma^{7}, 3$ 우, 3 juv. (ASU), same Republic and District, Altai State Nature Reserve, NW of Lake Teletskoye, cordon Baigazan, Sorbus sibirica and Salix, 447 m a.s.1., 3.09.2005; 3 +o (ASU), same Republic and District, Altai State Nature Reserve, NE of Lake Teletskoye, cordon Kamga, floodplain of Malyi Meanok River, Betula pendula, 6.09.2005, all leg. M.B. Sakhnevich; $3 \sigma^{\top} \sigma^{\top}, 6$ 우, 6 juv. (ASU), same Republic, Ulagan District, $28 \mathrm{~km}$ N of Aktash, Ulagan Pass, crooked Pinus sibirica and Larix sibirica forest with Betula rotundifolia, in moss, $2080 \mathrm{~m}$ a.s.1., 31.07.2006; $1 \sigma^{7}$, 1 juv. (ASU), same Province and District, near Aktash, top of Mt Sardyma, $50^{\circ} 20^{\prime} 02^{\prime \prime} \mathrm{N}, 87^{\circ} 34^{\prime} 46^{\prime \prime} \mathrm{E}$, Pinus sibirica and Larix sibirica forest, motley grass vegetation, $1790 \mathrm{~m}$ a.s.1., 5.08.2006; 1 \% (ASU), same Republic, Ongudai District, Tutugoi River, Betula pendula, 9.08.2006; 1 + (ASU), same Republic, Ulagan District, ca. 18 air$\mathrm{km}$ NNW of Aktash, N part of Lake Sorulukel, $50^{\circ} 27^{\prime} 44^{\prime \prime} \mathrm{N}$, $87^{\circ} 30^{\prime} 24^{\prime \prime}$ E, Betula rotundifolia, Salix glauca and Pentaphylloides fruticosa, motley grass vegetation, green mosses, $1817 \mathrm{~m}$ a.s.l., 9.08.2007; $3 \bigcirc^{\top} \sigma^{7}, 6$ 우, 12 juv., 1 fragm. (ASU), same Republic and District, ca. 18 air-km NNW of Aktash, NW part of Lake Sorulukel, Pinus sibirica and Larix sibirica forest, hill top, 10.08.2007; 1 厂 , 3 juv. (ASU), same Republic and District, ca. 18 air-km NNW of Aktash, NW part of Lake Sorulukel, foot of N slope of Aigulakskii Mt. Range, Pinus sibirica and Larix sibirica forest with Betula rotundifolia, Vaccinium vitis-idaea, Equisetum and Sphagnum, 11.08.2007; $4 \sigma^{7} \sigma^{7}, 5$ juv. (ASU), same Republic and District, ca. 18 air-km NNW of Aktash, NE part of Lake Sorulukel, Larix sibirica and Pinus sibirica forest with Vaccinium vitis-idaea, 13.08.2007, all leg. P.S. Nefediev, J.S. Nefedieva; 3 
$\bigcirc^{7} \bigcirc^{7}, 3$ ㅇ (ASU), Russia, southwestern Siberia, Republic of Altai, Turochak District, Altai State Nature Reserve, NW of Lake Teletskoye, cordon Baigazan, 51 $45^{\prime} 34.9^{\prime \prime} \mathrm{N}, 87^{\circ} 25^{\prime} 55.9^{\prime \prime} \mathrm{E}$, Padus avium and Sorbus sibirica, $460 \mathrm{~m}$ a.s.1., 30.09.2013; 1 or, 4 Oᄋ (ASU), same Republic and District, Altai State Nature Reserve, NW of Lake Teletskoye, cordon Baigazan, $51^{\circ} 45^{\prime} 33.7^{\prime \prime} \mathrm{N}, 87^{\circ}$ $25^{\prime} 58.9^{\prime \prime}$, Padus avium and Sorbus sibirica, $468 \mathrm{~m}$ a.s.1., 30.09. 2013; 1 (ASU), same Republic and District, Altai State Nature Reserve, NW of Lake Teletskoye, cordon Baigazan, $51^{\circ} 45^{\prime} 35.0^{\prime \prime} \mathrm{N}$, $87^{\circ} 26^{\prime} 02.3^{\prime \prime}$ E, Salix caprea, 482 m a.s.1., 30.09.2013; $1 \sigma^{\top 7}, 2$ 우 (ASU), same Republic and District, Altai State Nature Reserve, NW of Lake Teletskoye, cordon Baigazan, $51^{\circ} 45^{\prime} 32.1^{\prime \prime} \mathrm{N}, 87^{\circ}$ $25^{\prime} 54.8^{\prime \prime} \mathrm{E}$, Padus avium, $454 \mathrm{~m}$ a.s.1., 1.10.2013; 2 ○ $^{\top}, 8$ 우 (ASU), same Republic and District, Altai State Nature Reserve, NW of Lake Teletskoye, cordon Baigazan, $51^{\circ} 45^{\prime} 34.1^{\prime \prime} \mathrm{N}$,

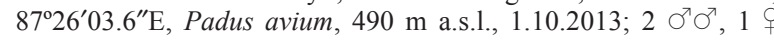
(ASU), same Republic and District, Altai State Nature Reserve, NW of Lake Teletskoye, cordon Baigazan, $51^{\circ} 45^{\prime} 32.7^{\prime \prime} \mathrm{N}, 87^{\circ}$ 26'05.8"E, Padus avium and Betula, $481 \mathrm{~m}$ a.s.1., 1.10.2013; 1 乃, 19 (ASU), same Republic and District, Altai State Nature Reserve, NW of Lake Teletskoye, cordon Baigazan, $51^{\circ} 45^{\prime} 34.4^{\prime \prime} \mathrm{N}, 87^{\circ}$ $25^{\prime} 51.3^{\prime \prime} \mathrm{E}$, Padus avium, Betula and Salix caprea, $465 \mathrm{~m}$ a.s.1., 3.10.2013; 3 우 (ASU), same Republic and District, Altai State Nature Reserve, NW of Lake Teletskoye, cordon Baigazan, $51^{\circ}$ $45^{\prime} 34.4^{\prime \prime} \mathrm{N}, 87^{\circ} 25^{\prime} 45.9^{\prime \prime} \mathrm{E}$, Padus avium, $467 \mathrm{~m}$ a.s.1., 3.10.2013; $\mathrm{O}^{7}, 2$ 우 (ASU), same Republic and District, Altai State Nature Reserve, NW of Lake Teletskoye, cordon Baigazan, $51^{\circ} 45^{\prime} 35.0^{\prime \prime} \mathrm{N}$, $87^{\circ} 25^{\prime} 42.2^{\prime \prime} \mathrm{E}$, Padus avium, $470 \mathrm{~m}$ a.s.1., 3.10.2013; $2 \mathrm{O}^{7} \mathrm{O}^{7}, 4$ 우 (ASU), same Republic and District, Altai State Nature Reserve, NW of Lake Teletskoye, cordon Baigazan, $51^{\circ} 45^{\prime} 31.6^{\prime \prime} \mathrm{N}, 87^{\circ}$ 25'39.1"E, Padus avium, Salix caprea and Betula, $448 \mathrm{~m}$ a.s.1. 3.10.2013; 1 ㅇ (ASU), same Republic, Ulagan District, Altai State Nature Reserve, S of Lake Teletskoye, cordon Chiri, $51^{\circ} 21^{\prime} 40.9^{\prime \prime} \mathrm{N}$, 87 50'19.7"E, $444 \mathrm{~m}$ a.s.1., Betula pendula and Padus avium, 9.07.2014; 1 juv. (ASU), same Republic, Turochak District, Altai State Nature Reserve, central part of Lake Teletskoye, cordon Kok-

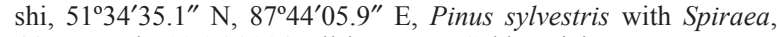
$445 \mathrm{~m}$ a.s.1., 10.06.2014, all leg. M.B. Sakhnevich.

DISTRIBUTION. The distribution area of the species seems to be confined to the Republic of Altai [Mikhaljova, 2017].

REMARKS. It seems very likely that G. kygae ranges also from Gornaya Shoriya, Kemerovo Area in the north and the Khakassian Republic in the east beyond its currently known distribution area.

\section{Family DIPLOMARAGNIDAE}

\section{Altajosoma bakurovi bakurovi (Shear, 1990)}

Altajosoma bakurovi - Mikhaljova, Golovatch, 2001:108; Mikhaljova, Nefediev, 2003: 86.

Altajosoma bakurovi bakurovi - Mikhaljova, 2004: 178, figs, 116: map; 2017: 218, figs, 219: map; Mikhaljova et al., 2008: 51; Nefedieva, Nefediev, 2008: 123; Nefediev, Nefedieva, 2013: 87; Nefedieva et al., 2014: 65; 2015: 147.

MATERIAL EXAMINED. 1 ○ (ASU), Russia, southwestern Siberia, Altai Province, Biysk, Molodezhnyi, right bank of Biya River, Betula pendula and Salix, litter, 13.10.2009; $1 \sigma^{7}, 1$ (ASU), same Province, Zalesovo District, near Peshchiorka, $54^{\circ} 05^{\prime} 00^{\prime \prime} \mathrm{N}, 84^{\circ} 49^{\prime} 31^{\prime \prime} \mathrm{E}$, Populus tremula forest with Betula pendula and Salix, $240 \mathrm{~m}$ a.s.1. 9.09.2015, all leg. P.S. Nefediev; 10 (ASU), same Province, Krasnogorskoe District, $3 \mathrm{~km} N$ of Bystryanka, Acer and Alnus stands along Chuya Tract, $52^{\circ} 19^{\prime} 39^{\prime \prime} \mathrm{N}$, $85^{\circ} 49^{\prime} 38^{\prime \prime}$ E, $215 \mathrm{~m}$ a.s.1., 15.08.2016, leg. P.S. Nefediev, J.S. Nefedieva; $1 \sigma^{7}$ (ASU), Russia, southwestern Siberia, Republic of Altai, Maima District, Gorno-Altaisk, floodplain of Maima River, foot of Mt Tugaya, 53 $59^{\prime} 03.2^{\prime \prime} \mathrm{N}, 85^{\circ} 53^{\prime} 56.5^{\prime \prime} \mathrm{E}$, Betula pendula and Acer, 276 m a.s.1., 9.10.2014; 1 (ASU), same Republic and District, Gorno-Altaisk, slope of Mt Tugaya, $53^{\circ} 59^{\prime} 01.8^{\prime \prime} \mathrm{N}$, $85^{\circ} 54^{\prime} 10.8^{\prime \prime} \mathrm{E}$, Betula pendula forest, $346 \mathrm{~m}$ a.s.1., 9.10.2014, all leg. P.S. Nefediev, J.S. Nefedieva.

DISTRIBUTION. The species is rather widespread in southwestern Siberia, likewise in the southern part of central Siberia, and it has previously been reported from the Tomsk, Novosibirsk and Kemerovo areas, the Republic of Altai and the Krasnoyarsk Province [Mikhaljova, 2017].

REMARKS. The above records of the species are new to the fauna of the Altai Province, where $A$. bakurovi bakurovi seems to inhabit its NE and E parts.

\section{Altajosoma deplanatum (Stuxberg, 1876)}

Altajosoma pinetorum Gulička, 1972: 37, figs. 1993: 6

Diplomaragna pinetorum — Shear, 1990: 38; Mikhaljova, Altajosoma pinetorum — Shelley et al., 2000: 62; Nefediev, Nefedieva, 2008a: 117.

Altajosoma deplanatum - Mikhaljova, 2000: 160, figs; 2004: 170, 171: figs, 162: map; 2013: 7; 2016: 12; 2017: 207, figs, 199: map; Mikhaljova, Golovatch, 2001: 108; Mikhaljova, Nefediev, 2003: 86; Mikhaljova et al., 2008: 51; Nefedieva, Nefediev, 2008: 123; Nefediev, Nefedieva, 2013: 87; Nefedieva et al., 2014: 65; 2015: 148 .

MATERIAL EXAMINED. $2 \sigma^{\top} \sigma^{\top}$ (ASU), Russia, southwestern Siberia, Altai Province, Pervomaiskii District, near Kostyaki, Kislukhinskii Nature Reserve, Pinus sylvestris forest with Betula pendula and ferns, 31.08.2014, leg. J.S. Nefedieva, P.S. Nefediev; $9 \sigma^{\top} \sigma^{\top}, 4$ 우 (ASU), same Province, Zalesovo District, near Peshchiorka, $54^{\circ} 05^{\prime} 00^{\prime \prime} \mathrm{N}, 84^{\circ} 49^{\prime} 31^{\prime \prime} \mathrm{E}$, Populus tremula forest with Betula pendula and Salix, $240 \mathrm{~m}$ a.s.1. 9.09.2015, leg. P.S. Nefediev.

DISTRIBUTION. Being originally described from an area between Mariinsk (the Kemerovo Area) and Achinsk (the Krasnoyarsk Province), the species has hitherto been reported from the Tomsk, Novosibirsk and Kemerovo areas, as well as the Altai and Khakassian republics [Mikhaljova, 2017].

REMARKS. The above records of $A$. deplanatum are new to the fauna of the Altai Province.

\section{Family KIRKAYAKIDAE}

\section{Teleckophoron montanum Gulička, 1972}

Teleckophoron montanum Gulička, 1972: 41, figs.

Teleckophoron montanum — Mikhaljova, 1993: 35; 2004: 193, 195: figs, 107: map; 2017: 236, 237: figs, 136: map; Shelley et al., 2000: 79; Mikhaljova, Golovatch, 2001: 113, 114: figs; Nefediev, Nefedieva, 2007: 161; 2008a: 117; 2008b: 62; 2013: 87; Nefedieva, Nefediev, 2008: 123; Nefedieva et al., 2014: 65; 2015: 152.

MATERIAL EXAMINED. 2 우 (ASU), Russia, southwestern Siberia, Republic of Altai, Ulagan District, Altai State Nature Reserve, S of Lake Teletskoye, cordon Chiri, mouth of Chiri River, Betula pendula forest, 11-12.08.2005, leg. P.S. Nefediev, J.S. Nefedieva.

DISTRIBUTION. The species has been recorded in the NE part of the Republic of Altai and in the S part of the Krasnoyarsk Province [Mikhaljova, 2017].

REMARKS. It seems likely that T. montanum occurs also in the Republic of Khakassia, a region situated between both known localities of the species. 


\section{Conclusions}

To date, at least 41 (sub)species from 19 genera, nine families and three orders are known to occur in the Altai region within southwestern Siberia, Russia. The julid Julus ghilarovi ghilarovi Gulièka, 1963, the anthroleucosomatid Ghilarovia cylindrica (Shear, 1990), and two diplomaragnids, Altajosoma bakurovi bakurovi (Shear, 1990) and A. deplanatum (Stuxberg, 1876), are recorded from the Altai Province for the first time.

ACKNOWLEDGEMENTS. We are most thankful to S.I. Golovatch (Moscow, Russia) who kindly checked the English of an advanced draft. Our deepest gratitude is extended to all collectors who donated us their material for study. The results were obtained within the framework of the state task No. 6.2884.2017/4.6 Ministry of Education and Science of the Russian Federation.

\section{References}

Babenko A.S., Nefediev P.S., Nefedieva J.S. 2009. [The fauna and population dynamics of millipedes (Diplopoda) of the Salair chern taiga] // Vestnik Tomskogo gosudarstvennogo universiteta, Seriya biologiya. No.319. P.182-185 [in Russian].

Dyachkov Yu.V. 2014. [Biodiversity and ecological peculiarities of millipedes in the Tigirek State Nature Reserve (Diplopoda)] // Materialy XIX mezhdunarodnoi ekologicheskoi studencheskoi konferentsii "Ekologiya Rossii i sopredelnykh territorii". Novosibirsk. P.41 [in Russian].

Enghoff H. 1985. The millipede family Nemasomatidae with the description of a new genus and a revision of Orinisobates (Diplopoda, Julida) // Entomologica Scandinavica. Vol.16. P.27-67.

Gulička J. 1972. [New millipedes (Diplopoda) from the USSR. Part 2] // Zoologicheskii zhurnal. Vol.51. No.1. P. 36-45 [in Russian, with English summary].

Mikhaljova E.V. 1993. The millipedes (Diplopoda) of Siberia and the Far East of Russia // Arthropoda Selecta. Vol.2. No.2. P.336.

Mikhaljova E.V. 2002. On some poorly-known millipedes from Siberia (Diplopoda) // Arthropoda Selecta. Vol.10 (for 2001). No.3. P.201-207.

Mikhaljova E.V. 2004. The millipedes (Diplopoda) of the Asian part of Russia. Sofia-Moscow: Pensoft Publishers. Series Faunistica $39.292 \mathrm{p}$.

Mikhaljova E.V. 2009. New species of the family Julidae Leach 1814 from Altai, Russia (Diplopoda, Julida) // Zootaxa. Vol.2235. P.59-68.

Mikhaljova E.V. 2013. New data on the millipede fauna (Diplopoda) of Altai, Russia // Far Eastern Entomologist. No.265. P.110.

Mikhaljova E.V. 2016. New species and new records of millipedes (Diplopoda) from the Asian part of Russia // Far Eastern Entomologist. No.316. P.1-25.

Mikhaljova E.V. 2017. [The millipede fauna (Diplopoda) of the Asian part of Russia]. Vladivostok: Dalnauka Publ. 336 p. [in Russian, with English summary].

Mikhaljova E.V., Golovatch S.I. 2001. A review of the millipede fauna of Siberia (Diplopoda) // Arthropoda Selecta. Vol.9 (for 2000). No.2. P.103-118.

Mikhaljova E.V., Marusik Yu.M. 2004. New data on taxonomy and fauna of the millipedes from the Russian Far East, Siberia and Mongolia (Diplopoda) // Far Eastern Entomologist. No.133. P.1-12.
Mikhaljova E.V., Nefediev P.S. 2003. A contribution to the millipede fauna of Siberia (Diplopoda) // Arthropoda Selecta. Vol.11 (for 2002). No.1. P.81-87.

Mikhaljova E.V., Nefediev P.S., Nefedieva J.S. 2007. New data on millipedes of the family Julidae (Diplopoda, Julida) from Altai, Siberia // Zootaxa. Vol.1541. P.57-63.

Mikhaljova E.V., Nefediev P.S., Nefedieva J.S., Dyachkov Yu.V. 2015. Genus Leptoiulus Verhoeff, 1894 new to the fauna of the Asian part of Russia, with description of a new species from the Altai and its comparison with the European Leptoiulus trilineatus (C.L. Koch, 1847) (Diplopoda, Julida, Julidae) // Zootaxa. Vol.3974. No.2. P.267-276.

Mikhaljova E.V., Nefediev P.S., Nefedieva J.S., Sakhnevich M.B., Dyachkov Yu.V. 2014. Review of the millipede genus Sibiriulus Gulicka, 1972, with descriptions of three new species from Altai, Siberia, Russia (Diplopoda, Julida, Julidae) // Zootaxa. Vol.3866. No.1. P.30-52.

Nefediev P.S. 2001. [On the fauna and ecology of Myriapoda in the environs of the village of Smolenskoe, Altai Province] // Landshafty Zapadnoy Sibiri: problemy issledovaniy, ekologiya $\mathrm{i}$ ratsionalnoe ispolzovanie. Materialy VII Mezhdunarodnoy mezhvuzovskoy konferentsii, posvyaschjonnoy Dnyu Zemli. Biysk: Biysk Pedagogical State University Publ. P.84-86 [in Russian]

Nefediev P.S. 2016. [Leptoyulyus tigirekskii (Leptoiulus tigirek)] // Krasnaya kniga Altaiskogo kraya. Tom 2. Redkie i nakhodyashchiesya pod ugrozoi ischeznoveniya vidy zhivotnykh. Barnaul: Altai State University Publ. P.30-31 [in Russian].

Nefediev P.S., Dyachkov Yu.V., Nefedieva J.S. 2014. Fauna and ecology of millipedes (Diplopoda) in the Tigirek State Nature Reserve, Russian Altai // Tuf I.H., Tajovský K. (eds.). 16th International Congress of Myriapodology. Book of abstracts. Institute of Soil Biology, BC ASCR \& Faculty of Science, Palacký University, Olomouc. P.63.

Nefediev P.S., Farzalieva G.Sh., Tuf I.H., Nedoev H.Kh., Niyazov S.T. 2017. Millipede and centipede assemblages on the northern and southern slopes of the lowland Altais, southwestern Siberia, Russia (Diplopoda, Chilopoda) // Tropical Natural History. Suppl.5. 17th International Congress of Myriapodology. 23-26 July 2017, Krabi, Thailand. Book of abstracts. P.13.

Nefediev P.S., Nefedieva J.S. 2007. [Biogeographical characteristic of the millipede fauna in the southeast of Western Siberia] // Ostroverkhova G.P. (ed.). Bioraznoobrazie bespozvonochnykh zhivotnykh. Sbornik materialov II Vserossiiskoi shkoly-seminara s mezhdunarodnym uchastiem. 24-26 October 2007, Tomsk. Tomsk: Deltaplan Publ. P.159-164 [in Russian].

Nefediev P.S., Nefedieva J.S. 2008a. [A historical review of faunistic investigations of millipedes (Diplopoda) in western Siberia] // Vazhov V.M. (ed.). Altai: ekologiya i prirodopolzovanie. Trudy VII rossiisko-mongolskoi nauchnoi konferentsii molodykh uchionykh i studentov. Vol.1. Biysk: Biysk Pedagogical State University Publ. P.117-120 [in Russian].

Nefediev P.S., Nefedieva J.S. 2008b. Zoogeographical analysis of the millipede fauna (Diplopoda) in the south-east of Western Siberia // Myriapoda and Onychophora of the World Diversity, Biology and Importance. Abstracts of 14th International Congress of Myriapodology. Staatliches Museum für Naturkunde, Görlitz. Peckiana. Vol.6. P.62.

Nefediev P.S., Nefedieva J.S. 2013. [Biodiversity and ecology of millipedes in the environs of Lake Teletskoye (Diplopoda)] // Izvestiya Altaiskogo gosudarstvennogo universiteta, Biologicheskie nauki. Vol.3(79). No.1. P.86-87 [in Russian, with English summary].

Nefedieva J.S., Nefediev P.S. 2008. Ecofaunistical investigations of millipedes (Diplopoda) in the environs of Lake Teletskoe // Myriapoda and Onychophora of the World Diversity, Biology and Importance. Abstracts of 14th International Congress of Myriapodology. Staatliches Museum für Naturkunde, Görlitz. Peckiana. Vol.6. P.123-124.

Nefedieva J.S., Nefediev P.S., Sakhnevich M.B., Dyachkov Yu.V. 2014. Distribution of millipedes (Diplopoda) along an altitudinal gradient in the south of Lake Teletskoye, Altai Mts // Tuf I.H., Tajovský K. (eds.). 16th International Congress of Myri- 
apodology. Book of abstracts. Institute of Soil Biology, BC ASCR \& Faculty of Science, Palacký University, Olomouc. P.65.

Nefedieva J.S., Nefediev P.S., Sakhnevich M.B., Dyachkov Yu.V 2015. Distribution of millipedes (Diplopoda) along an altitudinal gradient in the south of Lake Teletskoye, Altai Mts, Russia // ZooKeys. Vol.510. P.141-161.

Shear W.A. 1988. Systematic position of the milliped species Alloiopus solitaries Attems and the genus Ghilarovia Gulička (Chordeumatida, Anthroleucosomatidae) // Myriapodologica. Vol.2. No.8. P.51-58.
Shear W.A. 1990. On the Central and East Asian milliped family Diplomaragnidae (Diplopoda, Chordeumatida, Diplomaragnoidea) // American Museum Novitates. No.2977 P.1-40.

Shelley R.M., Sierwald P., Kiser S.B., Golovatch S.I. 2000. Nomenclator generum et familiarum Diplopodorum II. A list of the genus and family-group names in the class Diplopoda from 1958 through 1999. Sofia-Moscow: Pensoft Publishers. 167 p.

Responsible editor S.I. Golovatch 